\title{
Neuronal Nitric Oxide Synthase-Dependent S-Nitrosylation of Gephyrin Regulates Gephyrin Clustering at GABAergic Synapses
}

\author{
Borislav Dejanovic ${ }^{1}$ and Guenter Schwarz ${ }^{1,2,3}$ \\ ${ }^{1}$ Department of Chemistry, Institute of Biochemistry, ${ }^{2}$ Cologne Excellence Cluster on Cellular Stress Responses in Aging-Associated Diseases, and ${ }^{3}$ Center \\ for Molecular Medicine, University of Cologne, 50674 Cologne, Germany
}

\begin{abstract}
Gephyrin, the principal scaffolding protein at inhibitory synapses, is essential for postsynaptic clustering of glycine and GABA type A receptors $\left(\mathrm{GABA}_{\mathrm{A}} \mathrm{Rs}\right)$. Gephyrin cluster formation, which determines the strength of GABAergic transmission, is modulated by interaction with signaling proteins and post-translational modifications. Here, we show that gephyrin was found to be associated with neuronal nitric oxide synthase (nNOS), the major source of the ubiquitous and important signaling molecule NO in brain. Furthermore, we identified that gephyrin is S-nitrosylated in vivo. Overexpression of nNOS decreased the size of postsynaptic gephyrin clusters in primary hippocampal neurons. Conversely, inhibition of nNOS resulted in a loss of S-nitrosylation of gephyrin and the formation of larger gephyrin clusters at synaptic sites, ultimately increasing the number of cell surface expressed synaptic $\mathrm{GABA}_{\mathrm{A}} \mathrm{Rs}$. In conclusion, S-nitrosylation of gephyrin is important for homeostatic assembly and plasticity of GABAergic synapses.
\end{abstract}

Key words: clustering; GABAA receptor; gephyrin; nNOS; post-translational modification; S-nitrosylation

\section{Introduction}

Inhibitory signaling in the brain primarily takes place at gammaaminobutyric acid (GABA)-ergic synapses. Pentameric GABA type A receptors $\left(\mathrm{GABA}_{\mathrm{A}} \mathrm{Rs}\right)$ are ubiquitously expressed in neurons and clustered at postsynaptic sites. The number of postsynaptic receptors is dynamic and implicated in the regulation of virtually all aspects of brain function (Luscher et al., 2011).

A very crucial factor for clustering and stabilization of synaptic $\mathrm{GABA}_{\mathrm{A}} \mathrm{Rs}$ is gephyrin, the principal scaffolding protein at inhibitory postsynapses (Fritschy et al., 2008). Gephyrin directly interacts with synaptic $\mathrm{GABA}_{\mathrm{A}} \mathrm{R}$ subunits and is essential for their clustering and localization (Kneussel et al., 1999; Tretter et al., 2008, 2011; Mukherjee et al., 2011; Kowalczyk et al., 2013). In addition to its structural function, gephyrin fulfills important roles in $\mathrm{GABA}_{\mathrm{A}} \mathrm{R}$ dynamics and synaptic plasticity in vivo (Tyagarajan et al., 2011; Chen et al., 2012; van Versendaal et al., 2012). Gephyrin exerts its physiological functions by interacting with a variety of binding partners, ensuring their close spatial proximity at postsynaptic sites (Fritschy et al., 2008). Accordingly, gephyrin

\footnotetext{
Received Feb. 7, 2014; revised March 14, 2014; accepted April 16, 2014

Author contributions: G.S. and B.D. designed research; B.D. performed research; B.D. analyzed data; G.S. and B.D. wrote the paper.

This work was supported by the German Science foundation (DFG, SFB635: TPA11), the Center for Molecular Medicine, and the Fonds der Chemischen Industrie. We thank Jean-Marc Fritschy (UZH, Zurich, Switzerland) for providing $\mathrm{GABA}_{A} \mathrm{R}$ specific antibodies, and Joana Stegemann and Sabine Rügenberg for excellent technical assistance.

The authors declare no competing financial interests.

Correspondence should be addressed to Guenter Schwarz, Institute of Biochemistry, University of Cologne, Zülpicher Street 47, 50674 Cologne, Germany. E-mail: gschwarz@uni-koeln.de.

DOI:10.1523/JNEUROSCI.0531-14.2014

Copyright $\odot 2014$ the authors $\quad 0270-6474 / 14 / 347763-06 \$ 15.00 / 0$
}

malfunction and the resulting reduced strength of GABAergic synaptic transmission is implicated in neurological disorders, such as epilepsy, autism, and schizophrenia (Lionel et al., 2013; Dejanovic et al., 2014). Thus, any signaling that modulates GABAergic synapses is important for balancing neuronal networks and synaptic plasticity.

Nitric oxide (NO) is a ubiquitous and important signaling molecule regulating a wide range of cellular functions in different organs (Pacher et al., 2007). In the nervous system, NO has been found to modulate both excitation and inhibition. Although it has been shown to be involved in long-term potentiation (Lange et al., 2012) other studies found a modulation of GABAergic transmission by NO (Li et al., 2004; Zanelli et al., 2009; Cserép et al., 2011). Given that NO is involved in depolarization-induced suppression of inhibition (Makara et al., 2007), NO might be an important regulator of the excitatory/inhibitory balance in the brain (Le Roux et al., 2009). At the inhibitory synapse, anatomical and electrophysiological evidence suggest that NO is a retrograde signaling molecule that can potentiate presynaptic GABA release (Saransaari and Oja, 2006; Szabadits et al., 2007; Zanelli et al., 2009). However, the function of NO at the postsynaptic site is much less explored.

In general, the main routes of action of NO include either the production of cGMP and activation of downstream pathways or post-translational modification of cysteine residues in proteins by the formation of nitrosothiol groups, a process called S-nitrosylation (Hardingham et al., 2013). Neuronal NO synthase (nNOS or NOS1), is the major source of NO in the brain and has been found at GABAergic postsynapses (Szabadits et al., 2007; Cserép et al., 2011). Despite the multiple lines of evidence that nNOS-produced NO has an impact on GABAergic function, 
neuronal proteins that associate with nNOS have not been identified yet.

Here, we show that gephyrin interacts with nNOS and detected gephyrin-nNOS complexes in soma and dendrites of primary hippocampal neurons. Additionally, we identified that gephyrin is physiologically S-nitrosylated, which regulates the sizes of postsynaptic gephyrin clusters and hence modulates cell surface expression of synaptic $\mathrm{GABA}_{\mathrm{A}} \mathrm{Rs}$.

\section{Materials and Methods}

Expression constructs and reagents. Enhanced green fluorescent proteintagged gephyrin has been described previously (Lardi-Studler et al., 2007). nNOS was cloned in frame into the pcDNA3.1(+)myc/His A using KpnI and XbaI restriction sites. Where indicated, $100 \mu \mathrm{M}$ N5-(1Imino-3-butenyl)-L-ornithine (L-VNIO; from a $1000 \times$ stock in DMSO) was added to the growth medium for $14 \mathrm{~h}$. SNOB1 reagent $(1 \mathrm{mg} / \mathrm{ml})$ dissolved in DMSO served as a $200 \times$ stock and was freshly diluted in protein lysates.

Cell culture and transfection. HEK293 cells were cultured in DMEM (GE Healthcare) and 10\% FCS supplemented with L-glutamine and transfected with polyethylenimine using standard protocols. Primary hippocampal neurons were cultured as previously described (Dejanovic et al., 2014). Neurons were usually transfected after 10 days in vitro (DIV) using Lipofectamine 2000 (Invitrogen) according to the manufacturer's manual and cultured for additional $3 \mathrm{~d}$.

Immunostaining and quantification of cultured cells. Immunostaining and laser scanning microscopy of cultured cells have been described previously (Dejanovic et al., 2014). Antibodies used for the immunostaining: mouse anti-gephyrin (1:50 cell culture supernatant, clone 3B11, RRID:AB_887719); mouse anti-myc ( $1: 15$ cell culture supernatant, clone 9E10, RRID:AB_2266850); rabbit anti-vesicular GABA transporter (VGAT; 1:500, Synaptic Systems, AB_887871). Secondary antibodies were goat raised AlexaFluor 488 and 568 antibodies (1:500, Invitrogen). Images were acquired as a $z$-stack with three optical sections of $0.5 \mu \mathrm{m}$ in depth. Maximum intensity projections were created and analyzed using NIS Elements 3.2 (Nikon) software. After background subtraction, gephyrin clusters and VGAT puncta were quantified within two $20 \times 5$ $\mu \mathrm{m}$ regions-of-interest (ROI) per neuron using the analyze particles option in NIS Elements setting the minimal-threshold of a cluster to $>0.08$ $\mu \mathrm{m}^{2}$. Cluster size was averaged per neuron and mean values were compared for significance using Student's $t$ test with the software SigmaPlot (Systat Software). Gephyrin localization in respect to VGAT was analyzed by blinded manual counting of opposed clusters within two ROI per neuron. Images were processed with the software ImageJ (NIH).

Coimmunoprecipitation. Fresh mouse brains were cut into small cubes and homogenized using a Potter S (Sartorius) in lysis buffer (PBS, 0.5\% Triton X-100, protease and phosphatase inhibitor cocktail, Roche). The postnuclear fraction was incubated with primary antibodies for $2 \mathrm{~h}$ at room temperature before $20 \mu \mathrm{l}$ of protein-A/G Sepharose beads (Santa Cruz Biotechnology) were added for another $2 \mathrm{~h}$. The beads were washed three times with PBS. Adsorbed proteins were eluted from the beads by boiling in $50 \mu \mathrm{l}$ SDS-loading buffer containing $\beta$-mercatoethanol. Immunoprecipitated samples were subjected to SDS-PAGE followed by immunoblotting. Primary antibodies used for immunoprecipitation: anti-nNOS (Santa Cruz Biotechnology, RRID:AB_630935) and anti-SNitroso-cysteine (Sigma-Aldrich, RRID:AB_260785).

In situ PLA. Proximity ligation assay (PLA) was performed on primary hippocampal neurons cultured 14 DIV. The assay was performed using the Duolink system and was performed as described by the manufacturer (Olink). Omitting the rabbit-specific secondary probe served as an internal control in the assay. The following antibodies have been used: mouse anti-gephyrin (clone 3B11, RRID:AB_887719), mouse anti-neuroligin 2 (Synaptic Systems, 5E6), rabbit anti-nNOS (Santa Cruz Biotechnology, RRID:AB_630935).

Surface biotinylation. Two 6-well dishes with 600,000 neurons cultured 14 DIV were used per condition. Neurons were preincubated with 100 $\mu \mathrm{M}$ L-VNIO or the solvent for $14 \mathrm{~h}$. Neurons were rinsed twice with ice-cold PBS supplemented with $0.5 \mathrm{mM} \mathrm{MgCl}_{2}$ and $1 \mathrm{mM} \mathrm{CaCl}_{2}$. Surface proteins were biotinylated in a $20 \mathrm{~min}$ incubation step at $4^{\circ} \mathrm{C}$ in $1 \mathrm{ml} \mathrm{PBS}$ supplemented with $1 \mathrm{mg} / \mathrm{ml}$ sulfo-NHS-SS-biotin (Thermo Scientific). Unreacted biotin reagent was quenched by washing with $100 \mathrm{~mm}$ glycine dissolved in supplemented PBS buffer. Cells were lysed in $500 \mu \mathrm{l}$ PBS containing $2 \%$ Triton X-100, $0.2 \%$ SDS and protease inhibitor cocktail (Roche). After a brief sonication, cells were incubated for $1 \mathrm{~h}$ on ice and subjected to centrifugation $(10,000 \times g$ for $2 \mathrm{~min})$. From this, $50 \mu \mathrm{l}$ were saved as loading control and supernatants were incubated with Neutravidin beads (Thermo Scientific) for $2 \mathrm{~h}$ at room temperature or overnight at $4^{\circ} \mathrm{C}$.

Biotin switch assay. Cell homogenates were extracted with $2 \%$ SDS-buffer (2\% SDS, $50 \mathrm{~mm}$ Tris-HCl, pH 7.4, 5 mм EDTA, $0.1 \mathrm{~mm}$ neocuproine) and briefly sonicated. Subsequently, $20 \mathrm{~mm}$ methylmethanethiosulfonate was added to the lysate and rotated head-over-tail for $2 \mathrm{~h}$ at room temperature. Proteins were precipitated with acetone/methanol/ $\mathrm{H}_{2} \mathrm{O}$ (ration $4: 1.5: 3$ ) three times and $50 \mathrm{~mm}$ ascorbate was used to liberate the nitrosylated cysteine residues for $2 \mathrm{~h}$ at room temperature. Instead of ascorbate, $50 \mathrm{~mm}$ Tris was used as an internal control. Cysteine residues were labeled with $0.8 \mathrm{~mm}$ HPDP-biotin (Pierce) and affinitypurified with Neutravidin-beads (Pierce). Proteins were eluted from the beads with SDS-loading buffer and boiled for $5 \mathrm{~min}$.

Western blot analysis and antibodies. For immunoblotting, a standard protocol was followed and detection was performed using chemiluminescence and an ECL system with a cooled CCD camera (Decon Science Tec). The following primary antibodies were used and diluted in Trisbuffered saline $/ 0.5 \%$ Tween containing 1\% dry milk: anti-gephyrin (3B11, RRID:AB_887719), anti-nNOS (Cell Signaling Technology, C7D7, RRID:AB_2152485), anti-GFP (Santa Cruz Biotechnology, AB_641123), anti-myc (RRID:AB_2266850), anti-GABA $A_{A} \alpha 1$ (gift from from Jean-Marc Fritschy, UTH Zurich), anti-GABA ${ }_{A} \mathrm{R} \beta 2 / 3$ (Millipore, BD17, RRID:AB_2109419), and GABAAR $\gamma 2$ (Synaptic Systems, RRID:AB_2263066).

\section{Results \\ nNOS interacts with gephyrin}

Given the recently identified impact of nNOS-derived NO on GABAergic sites (Zanelli et al., 2009; Cserép et al., 2011), we wondered whether gephyrin, as major postsynaptic scaffolding protein, interacts with nNOS. Following immunoprecipitations with mouse brain lysates, nNOS specifically coimmunoprecipitated gephyrin, suggesting that both proteins are associated within the brain (Fig. 1A). To assess whether nNOS and gephyrin colocalize in cells, we coexpressed GFP-tagged gephyrin and myc-tagged nNOS in HEK293 cells and neurons. Upon heterologous expression in non-neuronal mammalian cells, gephyrin forms large cytosolic clusters, so-called "blobs" (Lardi-Studler et al., 2007), whereas nNOS was diffusively distributed (Fig. $1 B^{\prime}$ ). When coexpressed, a fraction of nNOS was enriched at gephyrin-blobs, whereas the major part of nNOS remained diffuse within the cell (Fig. $1 B^{\prime \prime}$ ). Likewise, nNOS-myc colocalized with gephyrin-GFP clusters in primary hippocampal neurons cultured $10+3$ DIV (Fig. 1C). Together, these results suggest that gephyrin and nNOS form a complex, whereas the interaction between the proteins seems rather weak.

Gephyrin presents a modular structure comprising three domains: the N-terminal G-domain, C-terminal E-domain, and the central C-domain (Fritschy et al., 2008). To identify the domain essential for nNOS interaction, we coexpressed GFP-tagged gephyrin domain variants with nNOS-myc in HEK293 cells. Upon coimmunoprecipitation with nNOS-myc, we could identify the E-domain of gephyrin as potential site of interaction (Fig. $1 D)$. To probe whether also endogenous gephyrin and nNOS form a complex in primary hippocampal neurons, we performed an in situ PLA that enables detections of protein-protein interactions at single molecular resolution. PLA signals were detected in the soma and along the dendrites in neurons, confirming the 

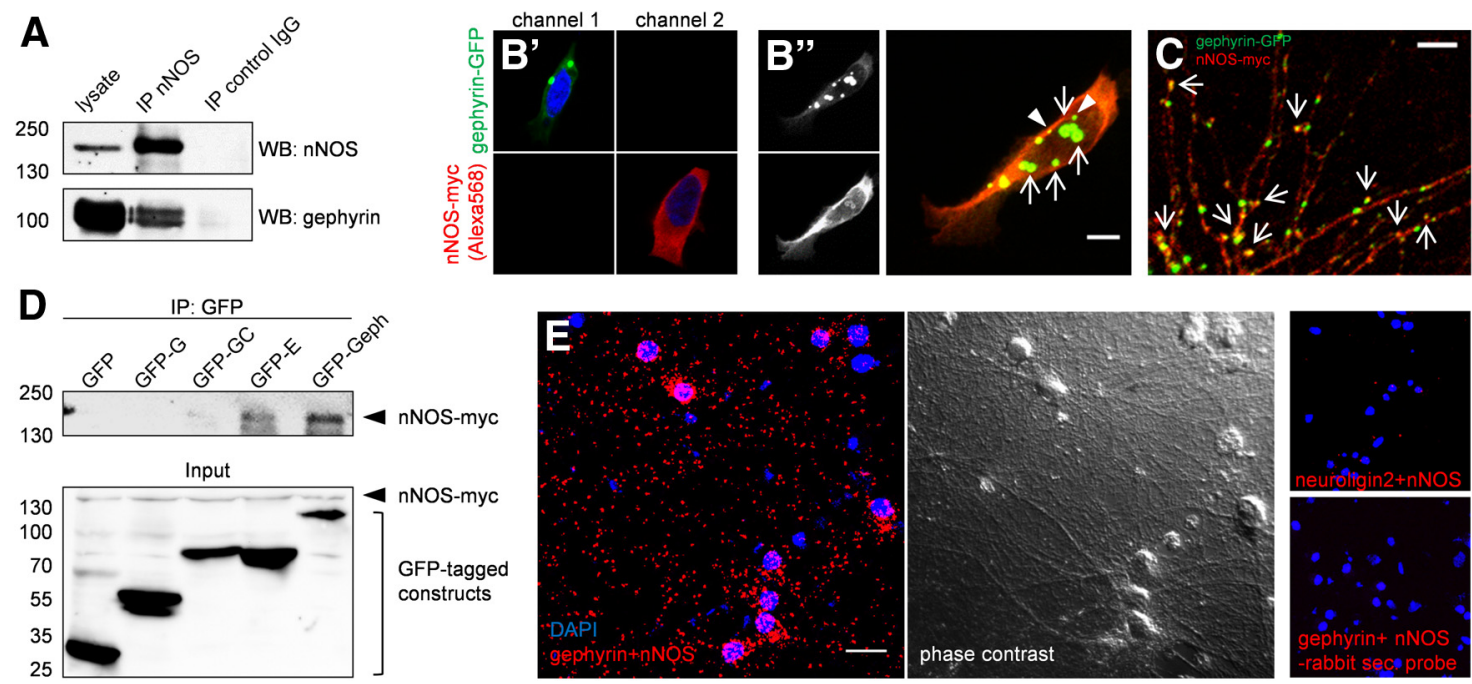

Figure 1. Gephyrin interacts with nNOS. $A$, Coimmunoprecipitation (IP) from brain lysates with nNOS specific or nonspecific control antibodies (control lgG). $\boldsymbol{B}^{\prime}$, GFP-tagged gephyrin forms large intracellular protein aggregates blobs upon expression in HEK293 cells, whereas myc-tagged nNOS is diffusively distributed. There is no bleed-through of the channels. $\boldsymbol{B}^{\prime \prime}$, Upon coexpression, a fraction of nNOS accumulates with gephyrin blobs (arrows), whereas other blobs show no increased nNOS-immunoreactivity (arrowheads).C, Coexpression of gephyrin-GFP and nNOS-myc in primary hippocampal neurons at $10+3$ DIV. Arrows point to colocalized immunoreactivity. D, Coimmunoprecipitation from HEK lysates expressing nNOS-myc and GFP-tagged gephyrin domains (G-, GC-, and E-domain) as well as holo-gephyrin (Geph). $\boldsymbol{E}$, In situ PLA using antibody-pairs as indicated in red. Scale bars: $\boldsymbol{B}^{\prime}, \boldsymbol{C}, 5 \mu \mathrm{m} ; \boldsymbol{E}, 10 \mu \mathrm{m}$.

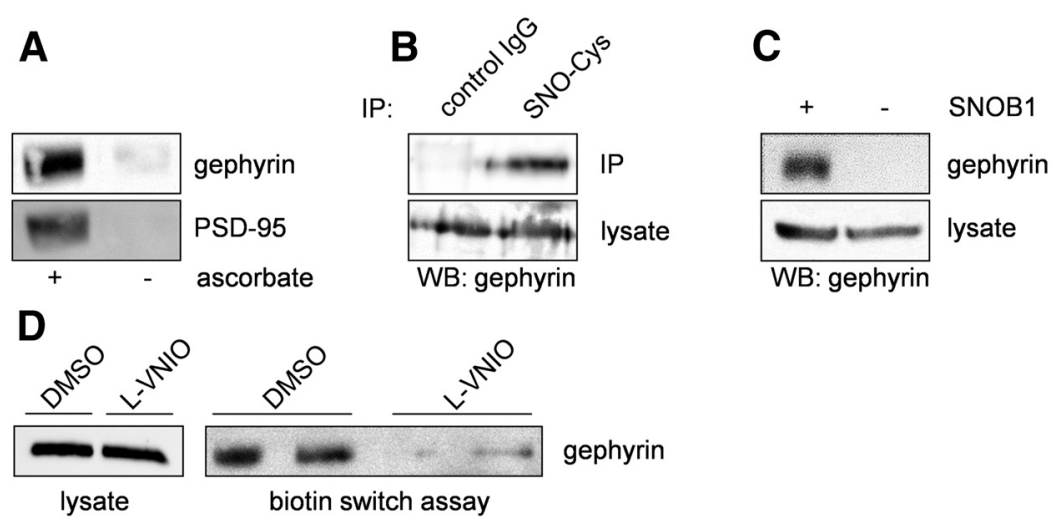

Figure 2. Gephyrin is S-nitrosylated in vivo. A, S-nitrosylation of gephyrin in mouse brain lysate demonstrated by the biotinswitch assay. Ascorbate dependence demonstrates specificity of the signal. $\boldsymbol{B}$, Immunoprecipitation of gephyrin from brain lysates with S-Nitroso (SNO)-cysteine specific antibodies. C, Affinity-purification of gephyrin from brain lysates using the SNO-binding (SNOB1) reagent. D, S-nitrosylation of gephyrin in primary hippocampal neurons following the incubation with DMSO or the nNOS-specific inhibitor L-VNIO monitored by the biotin-switch assay.

complex formation of gephyrin and nNOS (Fig. 1E). Only sporadic signals were detected for nNOS and the gephyrininteracting cell adhesion molecule neuroligin 2 (Poulopoulos et al., 2009), whereas no signals were detected without the rabbit specific secondary probe, both independently proving the specificity of the assay.

\section{Gephyrin is S-nitrosylated in vivo}

Given the identified spatial proximity to nNOS, we wondered whether gephyrin might be a target for S-nitrosylation by nNOSproduced NO. Therefore, we monitored S-nitrosylation of endogenous gephyrin in mouse brain lysates using the biotin-switch assay, which relies on the chemical exchange of nitrosylated cysteines to biotinylated cysteines in an ascorbate-dependent reaction. We observed a clear S-nitrosylation signal for gephyrin in brain-extract (Fig. 2A), similarly to the S-nitrosylation of the glutamatergic scaffolding protein PSD-95 that has been described recently (Ho et al., 2011). In the absence of ascorbate, no signal was detected. Next, we could also immunoprecipitate gephyrin from mouse brain lysates with an S-nitrosocysteine (SNO-cysteine) specific antibody (Fig. 2B). In a third approach, gephyrin was affinity-purified with Neutravidin beads after labeling of S-nitrosylated proteins in brain lysates with the biotin moietycarrying SNO-binding reagent 1 (SNOB 1; Fig. 2C). Next, we incubated primary hippocampal neurons with the nNOS-selective inhibitor L-VNIO and, performing a biotinswitch assay, found significantly decreased levels of S-nitrosylated gephyrin compared with DMSO-treated neurons (Fig. 2D). In aggregate, these data demonstrate that gephyrin is physiologically S-nitrosylated in the brain.

nNOS produced NO decreases the size of gephyrin clusters in neurons

We then asked whether nNOS derived NO influences postsynaptic clustering of gephyrin. Therefore, we transiently expressed gephyrin-GFP and nNOS-myc or mCherry in primary hippocampal neurons cultured $10+3$ DIV and subsequently analyzed gephyrin cluster size along dendrites using confocal laser scanning microscopy (Fig. $3 A$ ). We observed a significant decrease of gephyrin-GFP cluster area upon coexpression of nNOS as compared with control neurons coexpressing mCherry (Fig. 3B). Interestingly, inhibition of nNOS by applying $\mathrm{L}-\mathrm{VNIO}$ for $14 \mathrm{~h}$ resulted in gephyrin-GFP cluster sizes comparable to control neurons, thus reverting the effect of recombinant nNOS expression. These findings suggest that nNOS-produced NO controls the size of gephyrin clusters.

Inhibition of nNOS activity increases gephyrin cluster size and cell-surface expression of synaptic $\mathrm{GABA}_{\mathrm{A}} \mathrm{Rs}$

To assess whether NO, produced by endogenous nNOS, regulates clustering of endogenous gephyrin, we incubated primary hippocampal neurons with L-VNIO and immunostained gephyrin 

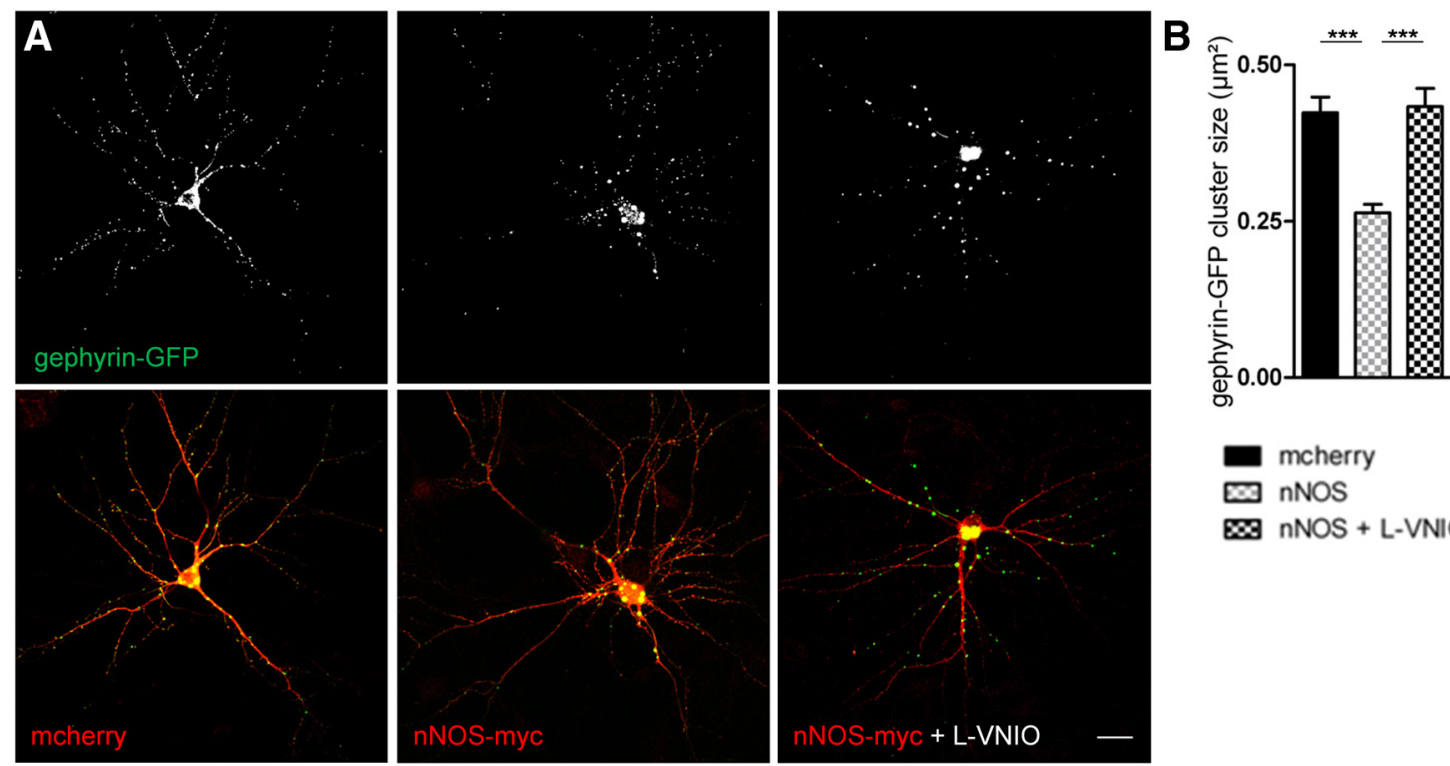

Figure 3. Increased nNOS expression leads to the formation of smaller postsynaptic gephyrin clusters. $A$, Representative images of gephyrin-GFP and mcherry or nNOS-myc expressed in primary hippocampal neurons at $10+3$ DIV. Scale bar, $20 \mu \mathrm{m} B$, Quantification of gephyrin-GFP cluster size in dendrites from hippocampal neurons expressing mcherry, nNOS, or nNOS in the presence of $100 \mu \mathrm{ML}$-VNI0. Size $\left(\mu \mathrm{m}^{2}\right)$ and quantified neurons $(n)$ : mCherry, $0.42 \pm 0.02, n=24 ; n N 0 S 0.26 \pm 0.01, n=27 ; \mathrm{nNOS}+\mathrm{L}-\mathrm{VNIO} 0.43 \pm 0.03, n=18 ; p<0.001 ;$ Student's $t$ test). Data are expressed as mean \pm SEM.

A

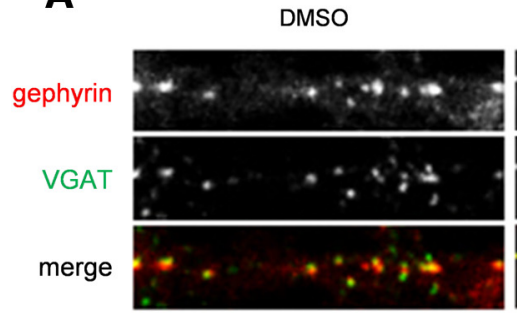

D

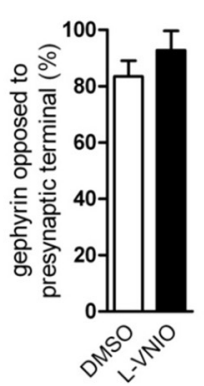

E

cell surface biotinylation

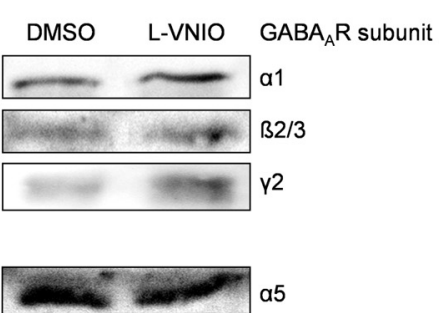

B

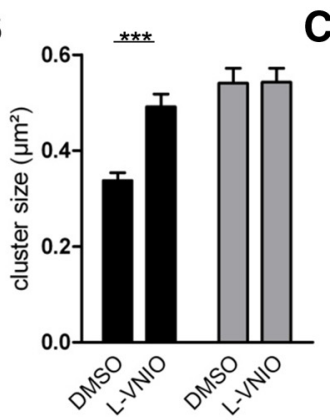

C

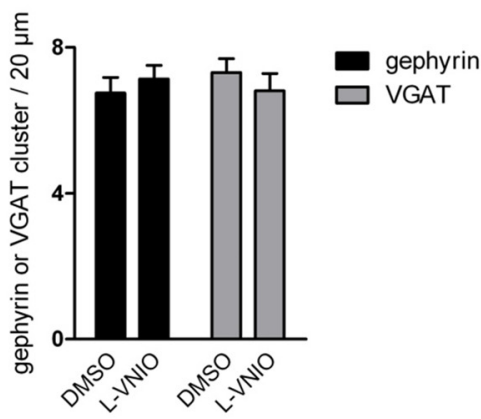

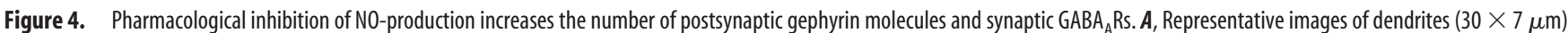
immunostained for gephyrin (red) and the presynaptic marker VGAT (green) at 14 DIV. B, Size of gephyrin clusters and VGAT puncta upon incubation with L-VNI0. Gephyrin cluster size: $0.33 \pm 0.02$ and $0.49 \pm 0.03 \mu \mathrm{m}^{2} ; n=24$ for DMSO and $n=18$ for L-VNI0, $p<0.001$, Student's $t$ test. $\boldsymbol{C}$, Density of dendritic gephyrin clusters and VGAT puncta (normalized to $20 \mu \mathrm{m}$ segments). $\boldsymbol{D}$, Quantification of colocalization between gephyrin clusters and VGAT in control and L-VNIO-treated neurons. $\boldsymbol{E}$, Representative Western blots of cell-surface biotinylation experiments. $\boldsymbol{F}$, Quantification of band intensities of cell surface expressed $\mathrm{GABA}_{A} \mathrm{R}$ subunits in L-VNIO-incubated neuronal cultures compared with control neurons. Intensity of bands in L-VNIO-incubated samples compared with DMSO-controls: $\alpha 1,121.1 \pm 3.5 \% ; \beta 2 / 3,124.1 \pm 6.0 \%$, and $\gamma 2,133.3 \pm 8.9 \% ; n=3,{ }^{*} p<0.05$, ${ }^{* *} p<0.01$, Student's $t$ test. All data are expressed as mean \pm SEM.

together with the VGAT as presynaptic marker (Fig. 4A). Using confocal laser scanning microscopy, we observed a significant increase in the size of gephyrin clusters upon nNOS inhibition, whereas the size of VGAT puncta was unaltered (Fig. $4 A, B$ ). The density of gephyrin clusters as well as VGAT puncta was unchanged upon L-VNIO incubation (Fig. 4C). The vast majority of the analyzed gephyrin clusters in control and L-VNIO-treated neurons were synaptically localized, as identified by apposition to VGAT-positive presynaptic terminals (Fig. 4A,D).

Next we investigated how the increased number of postsynaptically clustered gephyrin molecules influences cell surface expression of synaptic $\mathrm{GABA}_{\mathrm{A}} \mathrm{R}$ subunits. We performed cell surface biotinylation of primary hippocampal neurons cultured 14 DIV that have been incubated for $14 \mathrm{~h}$ with L-VNIO or the 
solvent DMSO. Interestingly, gephyrin-associated $\mathrm{GABA}_{\mathrm{A}} \mathrm{R}$ subunits $\alpha 1, \beta 2 / 3$, and $\gamma 2$ (Essrich et al., 1998; Mukherjee et al., 2011; Kowalczyk et al., 2013), but not the extra-synaptic $\alpha 5$, were significantly more abundant at the cell surface in L-VNIO-treated neurons compared with controls (Fig. $4 E, F$ ). In aggregate, these results suggest that reduced S-nitrosylation of gephyrin promotes growth of both gephyrin clusters and its interdependent $\mathrm{GABA}_{\mathrm{A}}$ Rs at postsynaptic sites.

\section{Discussion}

Neuronal NO signaling is considered to be synapse-specific as NO acts only over distances of $<1 \mu \mathrm{m}$ from the source of production (Namiki et al., 2005). Thus, interacting proteins are required to bind nNOS at the postsynaptic site. Several studies described nNOS localization at the GABAergic postsynapse (Zanelli et al., 2009; Cserép et al., 2011; Szabadits et al., 2011), whereas interacting proteins remained unknown. In this study, we show that gephyrin interacts with nNOS and that gephyrin is S-nitrosylated in vivo. To our knowledge, gephyrin is the first identified protein at inhibitory postsynapses that associates with nNOS and might be important for nNOS localization at individual synapses.

At GABAergic synapses $\mathrm{NO}$ acts as a retrograde messenger and modulates the release of GABA (Szabadits et al., 2007; Zanelli et al., 2009). By identifying S-nitrosylation of gephyrin, we uncovered novel and crucial function of nNOS at the postsynaptic site of GABAergic synapses. We found that gephyrin cluster size, a critical parameter of GABAergic synaptic plasticity (Tyagarajan et al., 2011; van Versendaal et al., 2012; Vlachos et al., 2013), is directly modulated by NO signaling. Likewise, increase in gephyrin cluster size upon pharmacological inhibition of nNOS, resulted in increased cell surface expression of synaptic $\mathrm{GABA}_{\mathrm{A}} \mathrm{Rs}$. Using VGAT as marker protein of inhibitory synapses, we did not observe morphological changes at presynaptic terminals (Fig. $4 A-C)$. NO signaling seems to be critical for clustering of gephyrin, but not for GABAergic synapse formation, as we did not see altered quantities of postsynaptic gephyrin clusters. Our results suggest that NO signaling impacts the size and stability of GABAergic postsynapses by modifying the scaffolding properties of gephyrin via S-nitrosylation. However, the exact molecular mechanism how S-nitrosylation influences clustering of gephyrin remains open.

It is noteworthy that gephyrin is extensively modified by posttranslational modifications; e.g., phosphorylation and acetylation (Herweg and Schwarz, 2012; Tyagarajan et al., 2013). Phosphorylation of gephyrin has been identified to influence GABAergic synapse formation and gephyrin clustering (Tyagarajan et al., 2011, 2013). Our present findings add to convergent lines of evidence that post-translation modifications of gephyrin regulate the complex dynamics of GABAergic synapses. Given that S-nitrosylation is known to have a broad pleiotropic influence on post-translation modifications (Hess and Stamler, 2012), a functional interplay between gephyrin S-nitrosylation and phosphorylation or other modifications is possible.

Importantly, nNOS activity is calcium-dependent, which provides a mechanism to spatially regulate the production of $\mathrm{NO}$, but it is not clear how calcium enters the cell at GABAergic synapses to activate nNOS. At glutamatergic synapses, nNOS is linked to NMDA-mediated neurotransmission and activated by calcium influx (Sattler et al., 1999). NMDA receptors have also been identified at GABAergic synapses in the hippocampus and were shown to activate nNOS (Szabadits et al., 2011), and thus might be the physiological source of calcium in such cases. An- other possibility is that calcium-influx is mediated by voltagegated calcium channels, which have been linked to $\mathrm{GABA}_{\mathrm{A}} \mathrm{R}$ expression and synaptic inhibition (Saliba et al., 2009).

In summary, our results show that S-nitrosylation of gephyrin is a novel mechanism that regulates the plasticity of GABAergic postsynapses. One might speculate that S-nitrosylation-dependent clustering of gephyrin influences the quantity of postsynaptically localized nNOS molecules and hence the amount of produced NO that could act as a retrograde messenger at the presynapse. Future studies will elucidate the exact molecular mechanisms underlying S-nitrosylation-dependent clustering of gephyrin and whether potentially the gephyrin-nNOS association plays a role in coordinating presynaptic and postsynaptic communication via $\mathrm{NO}$ signaling.

\section{References}

Chen JL, Villa KL, Cha JW, So PT, Kubota Y, Nedivi E (2012) Clustered dynamics of inhibitory synapses and dendritic spines in the adult neocortex. Neuron 74:361-373. CrossRef Medline

Cserép C, Szonyi A, Veres JM, Németh B, Szabadits E, de Vente J, Hájos N, Freund TF, Nyiri G (2011) Nitric oxide signaling modulates synaptic transmission during early postnatal development. Cereb Cortex 21:20652074. CrossRef Medline

Dejanovic B, Lal D, Catarino CB, Arjune S, Belaidi AA, Trucks H, Vollmar C, Surges R, Kunz WS, Motameny S, Altmüller J, Kohler A, Neubauer BA, Epicure Consortium, Nürnberg P, Noachtar S, Schwarz G, Sander T (2014) Exonic microdeletions of the gephyrin gene impair GABAergic synaptic inhibition in patients with idiopathic generalized epilepsy. Neurobiol Dis 67C:88-96. CrossRef Medline

Essrich C, Lorez M, Benson JA, Fritschy JM, Lüscher B (1998) Postsynaptic clustering of major GABAA receptor subtypes requires the gamma 2 subunit and gephyrin. Nat Neurosci 1:563-571. CrossRef Medline

Fritschy JM, Harvey RJ, Schwarz G (2008) Gephyrin: where do we stand, where do we go? Trends Neurosci 31:257-264. CrossRef Medline

Hardingham N, Dachtler J, Fox K (2013) The role of nitric oxide in presynaptic plasticity and homeostasis. Front Cell Neurosci 7:190. CrossRef Medline

Herweg J, Schwarz G (2012) Splice-specific glycine receptor binding, folding, and phosphorylation of the scaffolding protein gephyrin. J Biol Chem 287:12645-12656. CrossRef Medline

Hess DT, Stamler JS (2012) Regulation by S-nitrosylation of protein posttranslational modification. J Biol Chem 287:4411-4418. CrossRef Medline

Ho GP, Selvakumar B, Mukai J, Hester LD, Wang Y, Gogos JA, Snyder SH (2011) S-nitrosylation and S-palmitoylation reciprocally regulate synaptic targeting of PSD-95. Neuron 71:131-141. CrossRef Medline

Kneussel M, Brandstätter JH, Laube B, Stahl S, Müller U, Betz H (1999) Loss of postsynaptic GABA(A) receptor clustering in gephyrin-deficient mice. J Neurosci 19:9289-9297. Medline

Kowalczyk S, Winkelmann A, Smolinsky B, Förstera B, Neundorf I, Schwarz G, Meier JC (2013) Direct binding of GABAA receptor beta2 and beta3 subunits to gephyrin. Eur J Neurosci 37:544-554. CrossRef Medline

Lange MD, Doengi M, Lesting J, Pape HC, Jüngling K (2012) Heterosynaptic long-term potentiation at interneuron-principal neuron synapses in the amygdala requires nitric oxide signalling. J Physiol 590:131-143. CrossRef Medline

Lardi-Studler B, Smolinsky B, Petitjean CM, Koenig F, Sidler C, Meier JC, Fritschy JM, Schwarz G (2007) Vertebrate-specific sequences in the gephyrin E-domain regulate cytosolic aggregation and postsynaptic clustering. J Cell Sci 120:1371-1382. CrossRef Medline

Le Roux N, Amar M, Moreau AW, Fossier P (2009) Roles of nitric oxide in the homeostatic control of the excitation-inhibition balance in rat visual cortical networks. Neuroscience 163:942-951. CrossRef Medline

Li DP, Chen SR, Finnegan TF, Pan HL (2004) Signalling pathway of nitric oxide in synaptic GABA release in the rat paraventricular nucleus. J Physiol-London 554:100-110. CrossRef Medline

Lionel AC, Vaags AK, Sato D, Gazzellone MJ, Mitchell EB, Chen HY, Costain G, Walker S, Egger G, Thiruvahindrapuram B, Merico D, Prasad A, Anagnostou E, Fombonne E, Zwaigenbaum L, Roberts W, Szatmari P, Fernandez BA, Georgieva L, Brzustowicz LM, et al (2013) Rare exonic 
deletions implicate the synaptic organizer gephyrin (GPHN) in risk for autism, schizophrenia and seizures. Human molecular genetics 22:20552066. CrossRef Medline

Luscher B, Fuchs T, Kilpatrick CL (2011) GABAA receptor traffickingmediated plasticity of inhibitory synapses. Neuron 70:385-409. CrossRef Medline

Makara JK, Katona I, Nyíri G, Németh B, Ledent C, Watanabe M, de Vente J, Freund TF, Hájos N (2007) Involvement of nitric oxide in depolarization-induced suppression of inhibition in hippocampal pyramidal cells during activation of cholinergic receptors. J Neurosci 27:1021110222. CrossRef Medline

Mukherjee J, Kretschmannova K, Gouzer G, Maric HM, Ramsden S, Tretter V, Harvey K, Davies PA, Triller A, Schindelin H, Moss SJ (2011) The residence time of $\operatorname{GABA}(\mathrm{A}) \mathrm{Rs}$ at inhibitory synapses is determined by direct binding of the receptor alphal subunit to gephyrin. J Neurosci 31:14677-14687. CrossRef Medline

Namiki S, Kakizawa S, Hirose K, Iino M (2005) NO signalling decodes frequency of neuronal activity and generates synapse-specific plasticity in mouse cerebellum. J Physiol-London 566:849-863. CrossRef Medline

Pacher P, Beckman JS, Liaudet L (2007) Nitric oxide and peroxynitrite in health and disease. Physiol Rev 87:315-424. CrossRef Medline

Poulopoulos A, Aramuni G, Meyer G, Soykan T, Hoon M, Papadopoulos T, Zhang M, Paarmann I, Fuchs C, Harvey K, Jedlicka P, Schwarzacher SW, Betz H, Harvey RJ, Brose N, Zhang W, Varoqueaux F (2009) Neuroligin 2 drives postsynaptic assembly at perisomatic inhibitory synapses through gephyrin and collybistin. Neuron 63:628-642. CrossRef Medline

Saliba RS, Gu Z, Yan Z, Moss SJ (2009) Blocking L-type voltage-gated Ca2+ channels with dihydropyridines reduces gamma-aminobutyric acid type A receptor expression and synaptic inhibition. J Biol Chem 284:3254432550. CrossRef Medline

Saransaari P, Oja SS (2006) Modulation of GABA release by second messenger substances and NO in mouse brain stem slices under normal and ischemic conditions. Neurochem Res 31:1317-1325. CrossRef Medline

Sattler R, Xiong Z, Lu WY, Hafner M, MacDonald JF, Tymianski M (1999) Specific coupling of NMDA receptor activation to nitric oxide neurotoxicity by PSD-95 protein. Science 284:1845-1848. CrossRef Medline

Szabadits E, Cserép C, Ludányi A, Katona I, Gracia-Llanes J, Freund TF, Nyíri
G (2007) Hippocampal GABAergic synapses possess the molecular machinery for retrograde nitric oxide signaling. J Neurosci 27:8101-8111. CrossRef Medline

Szabadits E, Cserép C, Szonyi A, Fukazawa Y, Shigemoto R, Watanabe M, Itohara S, Freund TF, Nyiri G (2011) NMDA receptors in hippocampal GABAergic synapses and their role in nitric oxide signaling. J Neurosci 31:5893-5904. CrossRef Medline

Tretter V, Jacob TC, Mukherjee J, Fritschy JM, Pangalos MN, Moss SJ (2008) The clustering of GABA(A) receptor subtypes at inhibitory synapses is facilitated via the direct binding of receptor alpha 2 subunits to gephyrin. J Neurosci 28:1356-1365. CrossRef Medline

Tretter V, Kerschner B, Milenkovic I, Ramsden SL, Ramerstorfer J, Saiepour L, Maric HM, Moss SJ, Schindelin H, Harvey RJ, Sieghart W, Harvey K (2011) Molecular basis of the gamma-aminobutyric acid A receptor alpha3 subunit interaction with the clustering protein gephyrin. J Biol Chem 286:37702-37711. CrossRef Medline

Tyagarajan SK, Ghosh H, Yévenes GE, Nikonenko I, Ebeling C, Schwerdel C, Sidler C, Zeilhofer HU, Gerrits B, Muller D, Fritschy JM (2011) Regulation of GABAergic synapse formation and plasticity by GSK3betadependent phosphorylation of gephyrin. Proc Natl Acad Sci U S A 108: 379-384. CrossRef Medline

Tyagarajan SK, Ghosh H, Yévenes GE, Imanishi SY, Zeilhofer HU, Gerrits B, Fritschy JM (2013) Extracellular signal-regulated kinase and glycogen synthase kinase 3beta regulate gephyrin postsynaptic aggregation and GABAergic synaptic function in a calpain-dependent mechanism. J Biol Chem 288:9634-9647. CrossRef Medline

van Versendaal D, Rajendran R, Saiepour MH, Klooster J, Smit-Rigter L, Sommeijer JP, De Zeeuw CI, Hofer SB, Heimel JA, Levelt CN (2012) Elimination of inhibitory synapses is a major component of adult ocular dominance plasticity. Neuron 74:374-383. CrossRef Medline

Vlachos A, Reddy-Alla S, Papadopoulos T, Deller T, Betz H (2013) Homeostatic regulation of gephyrin scaffolds and synaptic strength at mature hippocampal GABAergic postsynapses. Cereb Cortex 23:2700-2711. CrossRef Medline

Zanelli S, Naylor M, Kapur J (2009) Nitric oxide alters GABAergic synaptic transmission in cultured hippocampal neurons. Brain Res 1297:23-31. CrossRef Medline 